\title{
Benthic foraminifera as bio-indicators of drill cutting disposal in tropical east Atlantic outer shelf environments
}

\author{
M. Mojtahid (1), F. Jorissen (1) *, J. Durrieu (2); F. Galgani (3), \\ H. Howa (1), F. Redois (1) and R. Camps (2)
}

(1) Laboratoire des Bio-Indicateurs Actuels et Fossiles (BIAF) UPRES EA 2644, Université d'Angers. 2, Boulevard Lavoisier, 49045 Angers Cedex, France, and Laboratoire d'Etude des Bio-Indicateurs Marins (LEBIM). Ker Chalon, 85350 lle D'Yeu, FRANCE

(2) TOTAL, département Environnement Opérations. Avenue Larribau, 64018 Pau, FRANCE.

(3) IFREMER, avenue J.-Monnet, 34203 Sète, FRANCE.

e-mail adresses: meryem.mojtahid@etud.univ-angers.fr (M. MOJTAHID) ; frans.jorissen@univ-angers.fr (F. JORISSEN) ; josiane.durrieu@total.com (J.DURRIEU) ; francois.galgani@ifremer.fr (F. GALGANI) ; helene.howa@univ-angers.fr (H. HOWA) ; fabrice.redois@univ-angers.fr (F ; REDOIS) ; roger.camps@total.com (R. CAMPS).

* corresponding author

\begin{abstract}
:
We present a study of benthic foraminiferal faunas from the outer continental shelf off Congo (tropical West Africa), with the aim to determine the impact of the discharge of oily drill cuttings on the sea floor environment, to judge the regenerating capacity of the benthic ecosystem, and to investigate the possibility to develop an environmental monitoring method for open marine continental shelf environments, based on benthic foraminifera. We studied the spatial distribution and microhabitats of living and dead foraminiferal faunas, sampled in April 2003, 4 years after the end of disposal activities, in the upper $3 \mathrm{~cm}$ of the sediment at 9 stations (about $180 \mathrm{~m}$ depth) offshore Congo, that were subject to various degrees of pollution by oily cuttings from 1993 until 1999.
\end{abstract}

Our results describe a zonation of foraminiferal faunas in the $750 \mathrm{~m}$ around the former disposal sites. At the immediate vicinity of the discharge points (within $70 \mathrm{~m}$ ), faunas are characterized by low foraminiferal densities. Faunas between $70 \mathrm{~m}$ and $250 \mathrm{~m}$ of the disposal sites have very high foraminiferal densities, with high percentages (about $80 \%$ ) of opportunistic taxa such as Bulimina aculeata, Bulimina marginata, Textularia sagittula, Trifarina bradyi and Bolivina spp. Between 250 and $750 \mathrm{~m}$ from the disposal site, foraminiferal densities decrease, and the percentages of opportunistic species are lower (40-60\% of indicator species). These results show that 4 years after the cessation of oily cutting disposal, strong environmental impact is limited to the $250 \mathrm{~m}$ around the disposal sites. We used these data to develop a quantitative pollution index, values of which are strongly correlated to distance to the disposal site. This foraminiferal index offers the possibility to quantify the impact of anthropogenic eutrophication in continental shelf environments, but its validity must be tested in other continental shelf environments.

Keywords: Benthic foraminifera; Outer shelf; Eutrophication; Bio-indicator; Drill mud; Opportunistic taxa; Oily cuttings 


\section{$\underline{\text { Introduction }}$}

Oil well drilling operations generate large quantities of fluids and cuttings, small pieces of rock carried to the surface by the drilling fluid ("mud") used to lubricate and cool the drill bit, and to maintain well pressure. The drill mud is recycled after the cuttings are separated by physical means (shale shakers, hydrocyclones, etc.). The cuttings are discharged, most often directly into the marine environment, but if oil based muds are used, depending on local regulations, cuttings may be discharged into the sea, shipped to shore for treatment, or reinjected into wells (Dalmazzone et al., 2004).

Since the onset of offshore drilling, drill cuttings and their disposal have received considerable attention, and drilling muds have been developed with increased biodegradability and lower toxicity. However, the impact of cutting discharge on marine ecosystems, and the re-establishment of the marine fauna after cessation of drill cutting disposal, is still badly known, especially in tropical and subtropical environments. Therefore, better methods have to be developed to quantify the environmental impact of drill cutting disposal, and the duration and intensity of the impact after cessation of disposal.

At the N'Kossa field off Congo, two oil operating platforms, NKF1 and NKF2 (Fig.1), were active from November 1993 to April 1999, and have been generating important discharges of cuttings impregnated with oil drill fluids. Two substances, hydrocarbons and barium, are present in important concentrations in these drill cutting discharges, and may pollute the surrounding marine ecosystems.

The cuttings contain a significant quantity of hydrocarbons, and are mixed with the autochthonous sediments by currents and bioturbation. Their discharge may enhance eutrophication and thus increase the ecosystem oxygen demand. Toxic hydrocarbon components may be responsible for additional environmental stress, which may influence faunal abundance. Under stressed conditions, some taxa will disappear, whereas more resistant taxa will increase in abundance, and highly stresstolerant taxa may appear.

Hydrocarbons are degraded on the seafloor in the oxic environments at the sediment-water interface, and by biologic activity of anaerobic benthic organisms within the sediment. Aerobic organisms burrow into the deeper dysoxic and anoxic sediments and transport some reduced components (such as hydrocarbons) to the oxygenated sediment-water interface.

Hydrocarbon concentrations in the sediment rapidly decrease with increasing distance from the drilling platforms. At the N'Kossa field, in 2003, 4 years after the cessation of drilling activities, values are comparable to normal background values between 100 and $500 \mathrm{~m}$ from the disposal site (Dalmazzone et al., 2004, Durrieu et al., 2004).

Barium $\left(\mathrm{BaSO}_{4}\right)$ is a major component of drilling fluids, and thus an excellent tracer of drill mud disposal. At the N'Kossa field, barium concentrations are high in the direct surroundings of the disposal sites, but strongly increased concentrations (with respect to the background values found at station 2) are found until $750 \mathrm{~m}$ from the discharge sites (Dalmazzone et al., 2004, Durrieu et al., 2004). High Barium concentrations are found farther away from the discharge area than increased hydrocarbon concentrations (until $250 \mathrm{~m}$ from the disposal site, see Fig. 2), suggesting that hydrocarbons tend to be bio-degraded whereas Barium is preserved. For instance, between 250 and $500 \mathrm{~m}$ from NKF1, the levels of Ba increase from 2000 (1 year after the end of discharge activities) to 2003, indicative of a spreading of contaminated sediments over time in more distal areas (Durrieu et al., 2004; Dalmazzone et al., 2004).

Between 2000 and 2003, Ifremer (French Research Institute for Exploitation of the Sea) in collaboration with TOTAL, organized a research project with two main objectives:

1) to evaluate quantatively the impact on the benthic ecosystem of drill cuttings contaminated by oil-based drilling fluids, and

2) to supervise seabed re-colonization after cessation of drill cutting disposal activities.

Foraminifera are among the more abundant protists in marine benthic environments (Murray, 1991). Because of their short life cycles, high biodiversity and specific ecological requirements of individual species, foraminifera react quickly to environmental disturbance, and can be successfully employed as bio-indicators of environmental change, such as those brought about by anthropogenic pollution (as defined by Kramer and Botterweg, 1991). Foraminiferal assemblages are easy to collect; 
foraminifera are commonly abundant, providing a highly reliable database for statistical analysis, even when only small sample volumes are available. Furthermore, many foraminiferal taxa secrete a carbonate shell, and leave an excellent fossil record, that may be used to characterise baseline conditions, and to reconstruct the state of the ecosystem prior to sampling.

Studies of the effects of pollution on benthic foraminiferal assemblages, and their possible use as pollution indicators were initiated in the early 1960's by Resig (1960) and Watkins (1961). In the last decennia, foraminifera have been increasingly used to monitor pollution in a wide range of marine environments, such as intertidal mudflats impacted by oil spillages (Morvan et al., 2004), harbours affected by heavy metal pollution (Armynot Du Châtelet et al., 2004), or eutrophicated continental shelves (Sharifi et al., 1991; Yanko and Flexer, 1991).

In April 2003, we sampled benthic foraminiferal faunas at 9 stations ( 180 m depth) around two sites off Congo (tropical Africa), where drill cuttings were deposited between November 1993 and April 1999. Due to its location close to the Congo River (discharge volume 40,600 $\mathrm{m}^{3} / \mathrm{s}$, Laraque et al., 2001) and the presence of South-North surface currents (Benguela current, long-shore drift; Mounganga, 1999) on the Congo shelf, the study area receives significant quantities of terrigenous sediments, rich in organic matter and nutrients, as shown by the high organic carbon content (12\% on average). Seasonal upwelling on the outer shelf (Voituriez and Herbland, 1982; Jansen et al., 1984) may add to the nutrients in the surface waters.

Nutrient input usually results in increased primary production, contributing to delivery of organic carbon on the sea floor. The oxic degradation of these organic substances by micro-organisms, in particular bacteria, leads to strong oxygen consumption in the benthic ecosystem, often leading to dysoxic to anoxic conditions in pore waters or even at the sea floor. Such natural eutrophication is common on inner shelf environments, e.g. close to the deltas of the Po (Jorissen, 1987), and Rhône and Mississippi rivers (Van der Zwaan and Jorissen, 1991). The high organic matter concentrations in our study area suggest that shelf areas off Congo are similarly naturally eutrophicated. In recent times, these natural eutrophication phenomena may be significantly amplified by anthropogenic activities in the catchment area, that result in strongly increased nutrient and organic matter concentrations in river waters (e.g. Rabelais and Turner, 2001).

In this study of benthic foraminiferal faunas from a naturally eutrophic region impacted by human activities, we concentrate on three aspects:

1) the density and composition of the living fauna. Due to the short live cycle of foraminifera (in general 3 months to 2 years, Murray, 1991), these characteristics inform us about the current ecological conditions, and thus, about the adaptation of the faunas to the physico-chemical environmental parameters resulting from the drill cutting disposal, that ended four years before sampling. Our study focuses on 2 different size fractions: the $>150 \mu \mathrm{m}$ fraction contains the adults of the larger species, whereas the 63-150 $\mu \mathrm{m}$ size fraction contains juveniles of larger species, as well as adult representatives of small, often highly opportunistic taxa. Especially these small opportunistic taxa may have a strong response to eutrophication and/or pollution phenomena;

2) the vertical distribution of the live faunas in the first centimetres of the sediment. This socalled microhabitat varies in function of the zero oxygen level, and the availability of nutritive substances within sediment (Jorissen et al., 1995). A better knowledge of the foraminiferal microhabitat may yield complementary information about the degree of ecosystem eutrophication;

3) the composition of subrecent faunas, preserved at several $\mathrm{cm}$ depth in the sediment. This subfossil fauna, that can be studied thanks to the preservation of carbonatic foraminiferal shells after the death of the organism, is composed of a mixture of the original, pre impact fauna, alive before the onset of drilling mud disposal, and the faunas that colonized the study area during and after the period of drill mud disposal. The comparison between this subrecent fossil fauna and the living faunas enables us to recognize species indicative of this specific type of human imposed environmental stress. Generally, responsive species show a strong contrast between an absence (or a low density) in the original fauna and a high abundance in the living faunas of the stations close to the drill mud disposal site. 


\section{Materials and methods}

The study area is located in the offshore Congo on the N'Kossa field, $60 \mathrm{~km}$ off Pointe Noire, at a water depth of $180 \mathrm{~m}$. Dumpings of LTMBF (Low Toxicity Mineral Oil Base Fluid) cuttings began in November 1993 and ended in April 1999. A study was undertaken after the first period of drilling in 1995, and was followed by 3 monitoring surveys in November 2000, March 2002 and April 2003. In this paper, we present results for the last survey. Samples were collected from the $7^{\text {th }}$ to the $18^{\text {th }}$ of April 2003 on a radial of 6 points around site NKF2 (the previous surveys from 2000 and 2002 suggest that drill muds were dispersed southward by bottom currents). In 2003, a seventh site was added northwest of the drill rig, and 3 sampling stations were added around the nearby drill cutting disposal site NKF1 (Fig. 1, table 1).

Methodology of measurements of all physico-chemical analyses (Ba, hydrocarbons, grain size, organic matter, nutrients, redox potential and tests of biodegradation) is given in Dalmazzone et al., 2004.

For the analysis of their micropaleontological content (foraminifera), Van Veen grab cores with apparently intact sediment surfaces were subsampled with a core with $4 \mathrm{~cm}$ inner diameter. The cores were sliced into $0.5 \mathrm{~cm}$ levels down to $1 \mathrm{~cm}$ and then in $1 \mathrm{~cm}$ levels down to $7 \mathrm{~cm}$ depth. All samples were preserved in 95\% ethanol with $1 \mathrm{~g} / \mathrm{l}$ Rose Bengal. In the laboratory, the collected samples were sieved over sieves of 63 and $150 \mu \mathrm{m}$ openings. For the fraction larger than $150 \mu \mathrm{m}$, foraminifera of the surface level $(A$ : $0-0.5 \mathrm{~cm})$ and of the $2-3 \mathrm{~cm}$ level (D) were picked without any preliminary treatment, under wet conditions (50\% ethanol). For the levels B $(0.5-1 \mathrm{~cm})$ and $C(1-2 \mathrm{~cm})$ as well as for samples of the granulometric fraction $63-150 \mu \mathrm{m}$, living Foraminifera were concentrated by density separation with trichloroethylene $(\mathrm{D}=1.46)$. Living as well as unaltered dead foraminifera should be found exclusively in the floated part. A check of the deposited sediment, revealing the absence of live individuals, showed the efficiency of the method. The study of the dead fauna was carried out on level D $(2-3 \mathrm{~cm})$. At this depth, most of the non-fossilizing arenaceous foraminifera have disappeared (Bizon and Bizon, 1985), and deeper living faunal elements will be correctly represented (Loubere, 1989). For the analysis of the dead fauna, samples were dried and split with an Otto microsplitter. Whole splits were counted until a minimum of 200 tests of foraminifera was obtained. All foraminifera selected were determined using taxonomic studies with emphasis on Atlantic Ocean shelf environments (Phleger, Parker and Pearson, 1953; Kouyoumontzakis, 1982; Schiebel, 1992; Jones, 1994; Fontanier et al., 2002; Duchemin et al., 2005).

\section{$\underline{\text { Results }}$}

Grain size analysis. The natural, unimpacted, sediment (station 2, $2 \mathrm{~km}$ south of the deposit site) shows a bimodal grain size distribution with maxima between 6 and $10 \mu \mathrm{m}$ and between 200 and 400 $\mu \mathrm{m}$ (Dalmazzone et al., 2004). Close to the point of discharge, an additional granulometric maximum between 20 and $60 \mu \mathrm{m}$ is present. This fraction is most abundant at station 13 (100 m south of the disposal site). In comparison to the values of 2002, in 2003, the fraction 20-60 $\mu \mathrm{m}$, that appears to be related to the discharge of cuttings, has a higher concentration at every station, with the exception of station 6 (70 m west of the disposal site), where its concentration slightly decreases (Dalmazzone et al., 2004).

Sediment organic matter and nutrients contents (Table 2). The study area is directly influenced by the input of sediment, nutrients and continentally-derived organic matter by the Congo River, and thus is naturally eutrophic (e.g., Kouyoumontzakis, 1979). This observation explains the elevated levels of organic matter at all stations (11.0 to $12.8 \%$ dry weight; $18.4 \%$ at station 6,70 m west of NKF2, the main disposal site; Table 2). Sediment nutrient levels are elevated; $0.14-0.25 \%$ d.w. of nitrogen (0.19\% at site 2, farthest away from the drill mud disposal sites) and 0.5-1.5 \%o d.w. of phosphorus. With the exception of the elevated organic matter content at station 6 , levels of organic matter, nitrogen and phosphorus in the areas around the disposal sites are similar to those at the reference station 2. No significant changes in nutrient levels were found between 2002 and 2003 (Dalmazzone et al., 2004). 
Hydrocarbon and Barium contents. Concentrations of hydrocarbons and Barium in the superficial sediments are presented in figure 2 and table 1 . Four zones can be defined:

- Zone 1 (station 6, $70 \mathrm{~m}$ west of NFK2) is characterized by very high hydrocarbon (> 100 \%o d.w.) and Barium (> 90 \%o d.w.) concentrations.

- Zone 2 (stations 13 and 4 south of NFK2, station 18, close to NKF1; within $250 \mathrm{~m}$ from the disposal sites) is characterised by intermediate hydrocarbon (> 2 \%o d.w.) and very high Barium (> 30 \%o d.w.) concentrations.

- Zone 3 (stations 17, 3 and 16 close to site NKF2, 19 and 20 close to site NKF1, between 250 and $750 \mathrm{~m}$ from the disposal sites) are characterised by low hydrocarbon values (0.02 and 0.09 $\%$ d.w.), but elevated Barium concentrations (1-10 \% d.w.).

- Station 2, at $2 \mathrm{~km}$ from the main disposal site, supposedly represents baseline conditions, but Barium concentrations are still slightly elevated (about $0.5 \%$ d.w.).

Compared to 2002 (Dalmazzone et al; 2004), hydrocarbon and Barium concentrations decreased significantly at station 6, but increased slightly in an area up to $250 \mathrm{~m}$ from the disposal site (stations 13 and 4; Dalmazzone et al., 2004), probably because cuttings are spread over a larger area by means of the bottom currents. In 2003, increased Barium concentrations were observed as far as $2000 \mathrm{~m}$ from the disposal site whereas hydrocarbons were not observed beyond $1000 \mathrm{~m}$.

Redox potential. At background station 2, the redox potential is $+41 \mathrm{mV}$, indicating that the sediment is sufficiently oxygenated to ensure the aerobic degradation of natural organic matter input. The redox potential increases progressively from $\sim(-240 \mathrm{mV})$ at the disposal site NKF1 to $\sim(+30 \mathrm{mV})$ at $730 \mathrm{~m}$ from the discharge point, correlated closely with the decreasing hydrocarbon concentration in the sediment (Durrieu et al., 2004).

Leaching, Microtoxicology tests, and Biodegradability of organic matter. The results from the leaching procedure and microtoxicology essays are presented in table 3. A significant release of hydrocarbons (90-110 $\mu \mathrm{g} / \mathrm{l})$ was observed at stations 6, 13 and 4, within 70, 100 and $230 \mathrm{~m}$ of disposal site NKF2 (Table 3). The SE values are about 6 times higher than those observed at background station 2. Only at station 4 (230 m from disposal site NKF2), the microtoxicity tests showed a partial inhibition of bacterial activity, which probably is not the result of hydrocarbon pollution, in view of the low hydrocarbon concentrations in the leachate (Dalmazzone et al., 2004).

The results of an aerobic organic matter degradation test, performed for the most contaminated stations 6, 13 and 4, are presented in table 4. For sediments collected at station 6 (70 m west of site NKF2), about 75\% of hydrocarbons were degraded after 90 days from the beginning of the experience. At stations 13 (100 m south of NFK2) and 4 (230 m south), these values are about $45 \%$ and $80 \%$, respectively. These results are variable, but confirm the high biodegradability of the hydrocarbons, at least under aerobic conditions.

Foraminiferal analyses.

Living fauna, $>150 \mu \mathrm{m}$ fraction (plate 1; appendix 2).

In general, the living faunas are poor in this size fraction, even for the relatively small sediment surface $\left(12.6 \mathrm{~cm}^{2}\right)$ sampled, and contain only minimal quantities of deformed tests. The total number of individuals found in the uppermost $3 \mathrm{~cm}$ of sediment (volume $=37.7 \mathrm{~cm}^{3}$ ) varies between 7 and 215 (appendix 3), corresponding to a density between 1.8 and 57.0 individuals/10 $\mathrm{cm}^{3}$ (Fig. 3a). Samples from stations 2, 3, 6, 17 and 19 contain fewer than 20 live individuals (less than 5.3 individuals $/ 10 \mathrm{~cm}^{3}$ ), so that percentage data are not relevant there. Samples from stations 4, 13, 16 and 18 (fig. 3a, appendix 3) contain more than $~ 50$ specimens (more than 13.2 individuals $/ 10 \mathrm{~cm}^{3}$ ).

- The fauna at station 13 (100 m south of NFK2; 97 specimens $\left.=25.7 \mathrm{ind} / 10 \mathrm{~cm}^{3}\right)$ is dominated by species of the genus Bulimina (B. marginata, $27.8 \%$ of the total living fauna; B.costata, 19.6 \%; B. aculeata, 12.4 \%); Uvigerina peregrina (13.4 \%), Trifarina bradyi (12.4 $\%)$ and Textularia sagittula (7.2 \%) are also common.

- The fauna at station 4 (230 m south of NKF2; 215 specimens $\left.=57.0 \mathrm{ind} / 10 \mathrm{~cm}^{3}\right)$ is dominated by Amphicoryna scalaris (20.5 \%), Eggerella sp. 1 (19.5 \%), Bulimina aculeata 
(14.9\%) and Bulimina marginata (9.3\%). Textularia sagittula (4.7 \%), Uvigerina peregrina (4.7\%) and Rosalina globularis (3.7\%) are present.

- The fauna at station 16 ( $500 \mathrm{~m}$ south of NFK2; 49 specimens $=13 \mathrm{ind} / 10 \mathrm{~cm}^{3}$ ) is dominated by Nonion scaphum (22.4\%) and Uvigerina peregrina (18.4\%). Bulimina marginata (8.2 \%) and Cancris auriculus (8.2\%) are common.

- The fauna of station 18 (70 m north ofNKF1; 85 specimens $\left.=22.5 \mathrm{ind} / 10 \mathrm{~cm}^{3}\right)$ resembles that at station 4 and it is dominated by Bulimina aculeata (20.0\%), Uvigerina peregrina (15.3 \%), Eggerella sp. 1 (14.1\%), Trifarina bradyi (9.4\%), Bulimina marginata (8.2 \%) and Textularia sagittula (7.1\%). Some specimens of Amphicoryna scalaris (5.9\%) are present.

The fauna is generally concentrated in the upper $1 \mathrm{~cm}$ (Table 5, fig. 4). At stations 2, 3 and 19, the faunas are too poor to recognize a vertical distribution. At the richest stations (4, 16 and 18), the density of the living benthic foraminifera varies from 57 to 205 individuals per $10 \mathrm{~cm}^{3}$ sediment volume in the first half centimeter, decreasing rapidly towards the deeper sediment levels. Only at station 13, the highest density (79 individuals per $\left.10 \mathrm{~cm}^{3}\right)$ is in the $0.5-1 \mathrm{~cm}$ level.

The deepest studied sediment interval (D: $2-3 \mathrm{~cm}$ ) contains more than 1 specimen only at stations 4, 13 and 19. The faunas below $1 \mathrm{~cm}$ depth are dominated by Bulimina aculeata (Appendix 2).

Living fauna, 63-150 $\mu \mathrm{m}$ fraction (plate 2; appendix 4).

In general, densities in this size fraction (uppermost $2 \mathrm{~cm}$ ) are rather similar in pattern to those found in the $>150 \mu \mathrm{m}$ fraction, although the faunas tend to be slightly richer (Fig. 3b, appendix 5), especially at station 6. In all cases, simple species diversity (species richness) is much higher than in the $>150 \mu \mathrm{m}$ fraction.

Faunas at stations 4, 13 and 18 contain 147 to 319 individuals per $25.2 \mathrm{~cm}^{3}$ (39.0 to 84.6 ind/10 $\mathrm{cm}^{3}$ ) are dominated by Bolivina spp., Bulimina spp. and Gyroidina sp.1, with significant Cassidulina crassa, Cassidulinoides bradyi, Nonionella turgida, Trifarina pauperata and Valvulineria bradyana.

The relatively high faunal densities at stations 4,13 and 18 contrast with the much lower densities at the 6 other stations (18 to 76 individuals for $25.2 \mathrm{~cm}^{3}=4.8$ to $20.1 \mathrm{ind} / 10 \mathrm{~cm}^{3}$ ).

The faunas contain juvenile specimens of taxa found in the $>150 \mu \mathrm{m}$ fraction, such as Bulimina aculeata, B. marginata and U. peregrina, but also several small-sized species that occur only in this size fraction, such as the various Bolivina species, Gyroidina sp.1, Cassidulinoides bradyi, Trifarina pauperata and Valvulineria bradyana (Fig. 3b, appendix 5). The composition of the faunas at these 6 stations resembles to that at stations 4,13 and 18 . The overall faunal variability is relatively limited. The stations within $230 \mathrm{~m}$ of the disposal sites are all rich in Bolivina and Bulimina species. Gyroidina sp.1 and some less frequent taxa, such as Trifarina pauperata, Valvulineria bradyana and Nonionella turgida, appear exclusively at these stations. Background station 2 differs from all other stations by the absence of Bulimina species. The scarce fauna (30 individuals $=11.9 \mathrm{ind} / 10 \mathrm{~cm}^{3}$ ) is dominated by $B$. striatula; the species Gyroidina sp.1 is represented by only one specimen.

At all stations, the 63-150 $\mu \mathrm{m}$ fauna is concentrated in the second half centimeter (B: 0.5-1 $\mathrm{cm}$ ), with a density from 21 to 362 individuals per $10 \mathrm{~cm}^{3}$ (Table 6, fig 4), whereas in the first half centimeter of the sediment there are from 2 to 98 individuals per $10 \mathrm{~cm}^{3}$.

Dead foraminiferal faunas (Appendix 6).

Specimens not colored by Rose Bengal consist of a mixture of those that inhabited the area before the start of drill mud disposal, and those living afterwards. The study of these faunas provides a time-averaged picture that may inform us about pre-pollution assemblages

The total number of dead benthic and planktic foraminifera varies strongly. Foraminiferal densities are very low in samples 6, 13, 4 and 18 (fig. 5a, table 7), within 230m of the disposal sites, probably because of dilution of sediment by drill cuttings. Stations 4, 6 and 18 are also characterized by a low PB-ratio (table 7).

The percentages of the most common species in the dead/fossil faunas are presented in fig. $5 \mathrm{~b}$ and 5c. At background station 2, stress-indicative species should have a minimal density in the living as well as dead assemblages. All dead faunas are strongly dominated by Uvigerina peregrina, with significant quantities of the species Cassidulina carinata, Bulimina marginata, Cibicides lobatulus, 
Nonion scaphum and Pseudoeponides falsobeccarii. Such an assemblage is typical of outer continental shelf environments under the influence of abundant organic inputs (Murray, 1991; Fontanier et al., 2002).

Despite this overall similarity, faunas at background station 2 differ from all others by the absence of B. aculeata, and low percentages of B. marginata, Trifarina bradyi and Textularia sagittula, species that are typical elements of the live faunas of some of the stations closest to the disposal sites. In comparison with the composition of the living faunas, all dead faunas are strongly enriched in U. peregrina, whereas the percentages of B. aculeata, B. costata and B. marginata, Amphicoryna scalaris and Nonion scaphum are much higher in the richest living assemblages.

Finally, the study of the dead faunas revealed important amounts of reworked Pleistocene foraminifera and glauconitic grains at all stations.

\section{Discussion}

The eutrophic nature of the region where our sites are located is documented by the high organic carbon levels, the composition of the total benthic foraminiferal faunas and the presence of a large quantity of fecal pellets in the sediment, but it contrasts with the low densities of the living faunas. The value of about 3 live individuals per $10 \mathrm{~cm}^{3}$ (> $150 \mu \mathrm{m}$ fraction) in the topmost $\mathrm{cm}$ at background station 2 is about two orders of magnitude lower than values at a $140 \mathrm{~m}$ deep station in the Bay of Biscay (Fontanier et al., 2002). Values of about 50-100 individuals per $10 \mathrm{~cm}^{3}$ (sites 4,13 and 18, within $230 \mathrm{~m}$ of the discharge sites) are similar to the values described by Fontanier et al. (2002).

The low foraminiferal densities in our study area may be the consequence of the presence of strong bottom currents that hamper foraminiferal colonization of the relatively coarse substrate, as corroborated by the very low percentage of clay, and by the important amounts of reworked Pleistocene foraminifera and glauconitic grains. However, the low foraminiferal densities may also be due to a dilution with very high amounts of silty and fine sandy sediments originating from the Congo river.

The density and composition of the foraminiferal faunas allow us to subdivide the 9 stations into four groups:

1) Group 1: Station 6, 70 m west of NKF2, contains a rather poor fauna, slightly richer in the 63-150 $\mu \mathrm{m}$ fraction, that is dominated by Bulimina spp., Bolivina spp., Gyroidina sp.1 and Trifarina pauperata.

2) Group 2: Stations 4, 13 and 18, < $250 \mathrm{~m}$ from the disposal sites, contain abundant foraminiferal faunas. In the $>150 \mu \mathrm{m}$ fraction, Bulimina marginata and B. aculeata are dominant, and $U$. peregrina is common at stations 13 and 18. In the 63-150 $\mu \mathrm{m}$ fraction, Bolivina spp. and Bulimina spp. are dominant. These taxa are accompanied by some other species (Gyroidina sp.1, Trifarina pauerata and Cassidulinoides bradyi), that are much less common in the dead faunas, differ between the stations, and that may be considered as indicator species of pollution.

3) Group 3: Stations 2, 3, 17 and 19, > $250 \mathrm{~m}$ from the disposal sites, are characterized by poor faunas in the $>150 \mu \mathrm{m}$ as well as in the 63-150 $\mu \mathrm{m}$ fraction, without clearly dominant species.

4) Group 4: Station 16, $730 \mathrm{~m}$ south of NKF2, contains intermediate numbers of foraminifera in both size fractions; faunas in the $>150 \mu \mathrm{m}$ fraction are dominated by $N$. scaphum, U. peregrina, C. auriculus and B. marginata, whereas the 63-150 $\mu \mathrm{m}$ contains also abundant Bolivina spp. The $>150 \mu \mathrm{m}$ fauna contains the same taxa as the fossil faunas found at most stations (including background station 2), although the percentage of $U$. peregrina is much lower.

Faunas in group 2 show considerable difference between stations. In the living fauna of station 13 (100 m South of NKF2), Bulimina costata (20.0\%), Trifarina bradyi (12.0\%), Uvigerina peregrina (13.0 \%), Textularia sagittula (7.0 \%) and, in the 63-150 $\mu \mathrm{m}$ fraction, Gyroidina sp.1 (21.1 $\%)$, Valvulineria bradyana (6.0 \%) and Trifarina pauperata (5.0 \%) are common to abundant. The former three species are rare in the dead fauna. The living fauna of station 4 (230 m south of NKF2) is dominated by Amphicoryna scalaris (20.0\%) and Eggerella sp.1 (20.0 \%). In the dead faunas, these species are rare. Textularia sagittula (5.0 \%), Rosalina globularis (4.0\%) and Trifarina bradyi (3.0\%) are equally rare in the fossil faunas. Uvigerina peregrina is present at this station with about $5.0 \%$. 
The 63-150 $\mu \mathrm{m}$ fraction contains very high numbers of bolivinids and of the species Gyroidina sp.1, Cassidulinoides bradyi, Valvulineria bradyana, Nonionella turgida and Trifarina pauperata. The living fauna of station 18 (70 m north of NKF1) resembles that of station 4, although the densities of Amphicoryna scalaris and Eggerella sp. 1 are lower and Trifarina bradyi, Textularia sagittula and Uvigerina peregrina are more common. Nonionella turgida is common in the $63-150 \mu \mathrm{m}$ fraction.

The comparison of the living fauna with the dead/fossil faunas, especially at station 2 (nonimpacted site) allows us to recognize groups of species typical for the impact of the oily mud drilling disposals. Dead fauna is at all stations strongly dominated by Uvigerina peregrina, with Bulimina marginata/aculeata, Cassidulina carinata, Nonion scaphum, Hanzawaia boueana and Pseudoeponides falsobeccarii. Uvigerina peregrina is known for its preference of open ocean environments characterised by enhanced organic matter fluxes (e.g., Lutze and Coulbourn, 1984; Lutze, 1986; Hermelin and Shimmield, 1990; Mackensen et al., 1995; Fariduddin and Loubere, 1997; Schmiedl and Mackensen, 1997; De Rijk et al., 1999; Kuhnt et al., 1999; Schmiedl et al., 2000; Huang et al., 2002). It has also been described in severely oxygen-depleted areas in the Arabian Sea OMZ (Hermelin and Shimmield, 1990; Jannink et al., 1998). Schmiedl et al. (1997) suggest, however, that, in the southern Angola Basin and the Cape Basin, U. peregrina avoids strong oxygen depletion, and occurs preferentially in TOC-rich (> 1\%) sediments from the lower slope, characterized by moderate oxygen deficiency (> $2 \mathrm{ml} / \mathrm{l}$ ). Fontanier et al. (2003) observed, at a $550 \mathrm{~m}$ deep station in the Bay of Biscay, that this species shows a particularly strong reproductive and growth response to phytodetritus deposits, and is less abundant during periods without a large supply of fresh organic matter. The important difference between our dead faunas, very rich in U. peregrina, and our living faunas (much poorer) suggest that in our study area, this species only reproduces during periods of strong primary production, that may be induced by seasonal upwelling events. In the live faunas from stations 4,13 and 18, U. peregrina in the $>150 \mu \mathrm{m}$ fraction consistently co-occurs with $T$. sagittula and T. bradyi (Fig. 3). The latter species are rare or absent in the fossil fauna, and seem to be characteristic of the eutrophied conditions generated by the drilling disposals.

All stations within $230 \mathrm{~m}$ of the disposal points (4, 6, 13 and 18) are characterized, in the $>$ $150 \mu \mathrm{m}$ fraction, by high percentages of Bulimina aculeata and Bulimina marginata. Bulimina aculeata is absent at the reference station 2. High densities of these species have often been considered typical for highly stressed environments, specifically by oxygen depletion (Murray, 1991). Bulimina costata is similarly known to survive dysoxic conditions (Jorissen, 1999). Although the P/B-ratio's are high for a $180 \mathrm{~m}$ deep outer shelf environment (Van der Zwaan et al., 1990), values at stations 4, 13 and 18 are minimal (Table 7). This corroborates the thesis of a significant eutrophication of the sea floor at sites, resulting in a strong productivity of benthic foraminifera. Amphicoryna scalaris, Eggerella sp. 1, and Rosalina globularis are abundant in the living faunas at station 4, present at station 18, but almost absent in the dead faunas. In the literature, these species are not known for their preferences or tolerances for stressed and/or eutrophic environments. $R$. globularis has been described as an epifaunal, often epiphytic species (e.g. Spindler, 1980; Murray, 1991), and we observed several living specimens attached to rock debris in the residues of station 4. Apparently, this species is able to colonize hard substrates, presented by the larger drill cuttings. We suspect that all three three species are early colonizers of drill cuttings.

In the 63-150 $\mu \mathrm{m}$ fraction, Bolivina spp. and Bulimina spp. are dominant elements at all stations. Both genera are known for their preference of food-rich areas, and their tolerance for lowoxygen conditions (e.g. Barbawidjaja et al., 1992). In the stations close to the disposal sites, these taxa are accompanied by other important species that may be considered as pollution-indicators. At stations 4, 13 and 18, Gyroidina sp.1, Trifarina pauperata and Valvulineria bradyana are always present. Station 6 contains nearly the same species, without Valvulineria bradyana.

If we compare the living faunas around sites NKF2 and NKF1 with the sub-fossil faunas at background station 2, we can define the extent of the impact of drill cutting disposal (fig. 6) as follows:

- Faunas found in stations 2, 3, 16, 17 and 19 (> $250 \mathrm{~m}$ from disposal sites) represent faunas, that are not (station 2), or little impacted by the drilling cutting deposits; 
- Stations 4, 13 and 18 (between $70 \mathrm{~m}$ and 250m from disposal sites) contain faunas with increased percentages of opportunistic species, indicating eutrophication, as also shown by a significant increase of the faunal density and colonization of deeper sediment intervals.

- Station 6 (70 m from the disposal sites), finally, comprises a rather poor fauna, dominated mainly by species of Bulimina, a taxon resistant to oxygen depletion. The absence of foraminifera deeper in the sediment suggests a minimal thickness of the oxygenated layer of the sediment, and anoxic conditions close to the sediment-water interface. Therefore, this site appears to represent the conditions of maximum impact.

Summarising, our data present a typical picture, with strongly impoverished faunas closest to the disposal site (Fig. 6). This area is surrounded by an aureole of high density faunas with important opportunistic species, that may be tolerant to the dysoxic conditions. This pattern is very similar to the macrofaunal succession described by Pearson (1985) around a sludge disposal site in the Firth of Clyde, and to the foraminiferal successions described by Alve (1995) around point sources of pollution in estuarine areas.

In order to quantify the impact of pollution due to drill cutting disposal, we developed an index based on the cumulative relative abundance (percentage of the total fauna) of all taxa indicative of stress and/or ecosystem eutrophication. For both size fractions (63-150 $\mu \mathrm{m}+>150 \mu \mathrm{m})$, the living faunas in the $0-2 \mathrm{~cm}$ interval were added, and percentages were calculated for the total $>63 \mu \mathrm{m}$ fraction (63-150 $\mu \mathrm{m}+>150 \mu \mathrm{m}$ fraction). Next, percentages for the taxa A. scalaris, B. dilatata, $B$. seminuda, B. spathulata, Bolivina sp.1, Bulimina spp., Eggerella sp. 1, Gyroidina sp. 1, N. turgida, $R$. globularis, T. sagittula, T. bradyi, T. pauperata, U peregrina and V. bradyana, that are considered indicative of conditions of natural or anthropogenic eutrophication and/or stress, have been summed. (Fig. 7). The cumulative percentage of these taxa is a function of the distance to the disposal sites $\left(\mathrm{r}^{2}=\right.$ 0.85). This foraminiferal index makes a clear distinction between strongly impacted sites (4, 6, 13 and 18, more than $60 \%$ indicator species), weakly impacted sites (3, 16, 17 and 19, 40-60\% indicator species), and a non impacted site (station 2) with less than $20 \%$ of indicator species.

\section{Conclusions.}

We propose to use living benthic foraminiferal faunas as bio-indicators of the impact of disposal of oily drill cuttings in a tropical outer shelf environment.

Chemical analyses show 4 years after the end of drill cutting disposal activities, the level of contamination of the sediment by hydrocarbons and Barium is still high in an area of $250 \mathrm{~m}$ around the discharge points, and decreases progressively further away, with hydrocarbon not perceptible beyond $1000 \mathrm{~m}$.

Foraminiferal faunas reflect a strong decrease of environmental impact with increasing distance from the disposal sites. Using the density and composition of the benthic foraminiferal faunas, in comparison with a reference site, we can distinguish three zones where faunas are affected:

- a first zone is within $100 \mathrm{~m}$ of the disposal site, represented by a single station (6), characterized by a poor fauna composed mainly of species resistant to oxygen depletion;

- a second zone, situated from about 100 to $250 \mathrm{~m}$ from the disposal sites (stations, 4, 13 and 18), contains a fauna typical of eutrophicated environments, characterised by a high faunal density and a strong dominance of opportunistic species.

- a third zone (stations 3, 16, 17 and 19), more than $250 \mathrm{~m}$, and until $730 \mathrm{~m}$ away from the disposal site and, appears to present a transitional situation, where the environmental impact is minimal, but still perceptible. Faunal densities are low, but the faunal composition still shows a slight increase of opportunistic taxa.

A quantitative index based on the proportions of all taxa indicative of natural and/or anthropogenic eutrophication and stress shows a very high correlation with the distance from the disposal sites. These results show that benthic foraminifera are suitable to monitor the impact of oil 
cutting disposal in the open marine environment. 4 years after cessation of drill cutting disposal, the impact is largely limited to a zone of $250 \mathrm{~m}$ around the disposal sites.

\section{Acknowledgements}

The authors acknowledge the financial support of the Conseil Général de la Vendée for the senior author. We are very grateful to the reviewers Ellen Thomas and Allessandra Asioli, who investigated much time in the correction of the first manuscript, leading to a strongly improved final version. 


\section{References.}

Alve, E., 1995. Benthic foraminiferal response to estuarine pollution: A review. Journal of foraminiferal research, 25, 190-203.

Armynot du Châtelet, E., Debenay, J. P., and Soulard, R., 2004. Foraminiferal proxies for pollution monitoring in moderately polluted harbors. Environmental Pollution 127, 27-40.

Barmawidjaja, D.M., Jorissen, F.J., Puskaric, S., and Van der Zwaan, G.J., 1992. Microhabitat selection by benthic foraminifera in the norther Adriatic Sea. Journal of Foraminiferal Research 22, 297-317.

Bizon G. and J.J., 1985. Distribution des foraminifères sur le plateau continental du Rhône. ECOMED. 84-94

Dalmazzone Ch., Blanchet D., Lamoureux S., Dutrieux E., Durrieu J., Camps R. and Galgani F., 2004. Impact of Drilling Activities in Warm Sea: Recolonization Capacities of Seabed. Oil \& Gas Science and Technology - Rev. IFP, 59, 625-647.

De Rijk, S., Jorissen, F.J., Rohling, E.J., Troelstra, S.R., 2000. Organic flux control on bathymetric zonation of Mediterranean benthic foraminifera. Marine Micropaleontology 40, 151-166.

Duchemin, G., Jorissen, F., Andrieux-Loyer F., Le Loc’h, F., Hily, C. and Philippon X., 2005. Living benthic foraminifera from «La grande vasière », French Atlantic continental shelf: faunal composition and microhabitats. Journal of Foraminiferal Research 35, in press.

Durrieu J. and Bouzet Ph., 2004. Seabed Recolonisation: N'Kossa Case. Society of Petroleum Engineers Inc. SPE 86710. Calgary. 8 p.

Fariduddin, M., Loubere, P., 1997. The surface ocean productivity response of deeper water benthic foraminifera in the Atlantic Ocean. Marine Micropaleontology 32, 289-310.

Fontanier, C., Jorissen, F., Licari L., Alexandre A., Anschutz P. and Carbonel P., 2002. Live benthic foraminiferal faunas from the Bay of Biscay: faunal density, composition, and microhabitats. Deep Sea Research Part I: Oceanographic Research Papers 49, 751-785.

Fontanier C., Jorissen F.J., Chaillou G., David C., Anschutz P. and Lafon V., 2003. Seasonal and interannual variability of benthic foraminiferal faunas at $550 \mathrm{~m}$ depth in the Bay of Biscay. DeepSea Research I 50, 457-494.

Hermelin, J.O.R., Shimmield, G.B., 1990. The importance of the Oxygen Minimum Zone and sediment geochemistry in the distribution of recent benthic foraminifera in the Northwest Indian Ocean. Marine Geology 91, 1- 29.

Huang, B., Jian, Z., Cheng, X., Wang, P., 2002. Foraminiferal responses to upwelling variations in the South China Sea over the last 220000 years. Marine Micropaleontology 47, 1- 15.

Jannink, N.T., Zachariasse, W.J., Van der Zwaan, G.J., 1998. Living (Rose Bengal stained) benthic foraminifera from the Pakistan continental margin (northern Arabian Sea). Deep-Sea Research, Part I 45 (9), 1483-1513. 
Jansen, J.H.F., Van Weering, T.C.E., Gieles, R., Van Iperen, J., 1984. Middle and late Quaternary oceanography and climatology of the Zaire-Congo fan and the adjacent eastern Angola Basin. Netherlands Journal of Sea Research 17, 201-249.

Jones, R.W., 1994. The Challenger Foraminifera. Oxford University Press, 149 pp.

Jorissen, F.J., 1987. The Distribution of Benthic Foraminifera in the Adriatic Sea. Marine Micropaleontology 12, 21-48.

Jorissen, F.J., 1988. Benthic foraminifera from the Adriatic Sea; Principles of phenotypic variation.Utrecht Micropal. Bulletin 37, 176 pp.

Jorissen, F.J., De Stigter, H.C. and Widmark, J.G.V., 1995. A conceptual model explaining benthic foraminiferal microhabitats. Marine Micropaleontology 26, 3-15.

Jorissen, F.J., 1999. Benthic foraminiferal microhabitats below the sediment-water interface. En: Sen Gupta, B. (éditeur): Ecology of recent foraminifera, Kluwer Academic Publishers, chapître $10,161-179$.

Kouyoumontzakis, G., 1979. La microfaune benthique du plateau continental congolais. Inventaire, répartition, stratigraphie du Quaternaire supérieur. Rapports avec le milieu sédimentaire. Thèse de Doctorat de spécialité, Aix-Marseille II.

Kouyoumontzakis, G., 1982. Le biotope à Cancris congolensis aux abords de l'estuaire du fleuve Congo. Océanographie tropicale, 17 (2), 139-144.

Kramer and Botterweg, 1991. Aquatic biological early warning systems: an overview. In: Jeffrey, D.W., Madden B. (eds) Bioindicators and environmental management. Academic press, London, 95-126.

Kuhnt, W., Hess, S., Jian, Z., 1999. Quantitative composition of benthic foraminiferal assemblages as a proxy indicator for organic carbon flux rates in the South China Sea. Marine Geology 156 (1-4), 123- 158.

Laraque A., Mahé G., Orange D., Marieu B., 2001. Spatiotemporal variations in hydrological regimes within Central Africa during XX th Century. Journal of Hydrology 245, 104-117.

Langezaal, S., 2003. The foraminiféral - bacterial connection: an interdisciplinary study of meiofaunal behaviour in the deeper marine redox zone. Geologica Ultraiectina 229, pp. 239.

Loubere, P., 1989. Bioturbation and sedimentation rate control of benthic microfossil taxon abundances in surface sediments: a theoretical approach to the analysis of species microhabitats. Marine Micropaleontology 14, 317-325.

Lutze, G.F., Coulbourn, W.T., 1984. Recent benthic foraminifera from the continental margin of northwest Africa: community structure and distribution. Marine Micropaleontology 8, 361-401.

Lutze, G.F., 1986. Uvigerina species of the eastern North Atlantic. In: Van der Zwaan, G.J., Jorissen, F.J., Verhallen, P.J.J.M., von Daniels, C.H. (Eds.), Atlantic-European Oligocene to Recent Uvigerina. Utrecht Micropaleontological Bulletins 35, 21-46.

Mackensen, A., Schmiedl, G., Harloff, J. and Giese, M., 1995. Deepsea Foraminifera in the South Atlantic Ocean: ecology and assemblage generation. Micropaleontology 41 (4), 342-358. 
Morvan, J., Le Cadre, V., Jorissen, F. and Debenay, J.P., 2004. Foraminifera as potential bioindicators of the «Erika » oil spill in the Bay of Bourneuf : Field and experimental studies. Aquatic living resources, 17, 317-322.

Mouganga, M.D., 1999. Les systèmes flèches-lagunes du littoral gabonais. Rapport partiel de terrain, activités 1998, Laboratoire GEOLITTOMER-BREST, Institut Universitaire Européen de la mer, Université de Bretagne occidentale, Brest : 30 pp.

Murray, J.W., 1991. Ecology and distribution. BENTHOS'90, Sendai, Tokai University Press.

Pearson, T.H., 1985. Benthic ecology in accumulating sludge-disposal site. Proceedings of the Fourth International Ocean Disposal Symposium. England, April 1985, Chapter 17, 195-200.

Phleger, F.B., Parker, F.L. and Peirson, J.F. 1953. North Atlantic Foraminifera. Repts.Swed.Deep-Sea Exped 7(1), 1-122.

Rabalais, N.N. and Turner, R.E., 2001. Coastal Hypoxia: Consequences for Living Resources and Ecosystems. Coastal and Estuarine Studies Series Vol. 58, American Geophysical Union. Washington, D.C. 463 pp.

Resig, J.M., 1960. Foraminiferal ecology around ocean outfalls off southern California. In: E. Person (Editor), Disposal in the marine environment. Pergamon Press, London, pp. 104-121.

Schiebel, R., 1992. Rezente benthische Foraminiferen in Sedimenten des Schelfes und oberen Kontinentalhanges im Golf von Guinea (Westafrika). Berichte Geologisch-Paläontologisches Institut und Museum Christian-Albrechts-Universität Kiel, Deutschland, n 51, 126 pp.

Sharifi, A.R., Croudace, I.W. Austin, R.L., 1991. Benthic foraminiferids as pollution indicators in Southampton Water, southern England, UK. Journal of micropaleontology 10 (1), 109113.

Schmiedl, G., Mackensen, A., 1997. Late Quaternary paleoproductivity and deep water circulation in the eastern South Atlantic Ocean: evidence from benthic foraminifera. Palaeogeography, Palaeoclimatology, Palaeoecology 130, 43- 80.

Schmiedl, G., Mackensen, A., Müller, P.J., 1997. Recent benthic foraminifera from the eastern South Atlantic Ocean: dependence of food supply and water masses. Marine Micropaleontology 32, 249-287.

Schmiedl, G., De Bovée, F., Buscail, R., Charrière, B., Hemleben, C., Medernach, L., Picon, P., 2000. Trophic control of benthic foraminiferal abundances and microhabitat in the bathyal Gulf of Lions, western Mediterranean Sea. Marine Micropaleontology 40, 167-188.

Spindler, M., 1980. The pelagic golfweed Sargassum Natans as a habitat for the benthic foraminifera Planorbulina acervalis et Rosalina globularis. Neues Jarhbuch für Geologie und Palöontologie Monatheft 9, 569-80.

Van der Zwaan, G.J. and. Jorissen, F.J., 1991. Biofacial patterns in river-induced shelf anoxia. From Tyson R.V and Pearson T.H., 1991 Modern and ancient continental shelf anoxia. Geological society Special 58, 65-82.

Van der Zwaan, G.J et Jorissen, F.J. and de Stigter, H.C., 1990. The depth dependency pf planktonic/benthic foraminiferal ratios : Constraints and applications. Marine geology 95, 1-16. 
Voituriez, B., Herbland, A., 1982. Comparaison des systèmes productifs de l'Atlantique Tropical Est: dômes thermiques, upwellings côtiers et upwelling équatorial. Rapports et ProcésVerbaux des Réunions-Conseil International Pour l’Exploration de la Mer 180, 114-130.

Watkins, J.G., 1961. Foraminiferal ecology around the Orange County, California, ocean sewer outfall. Micropaleontology 7(2), 199-206.

Yanko, V. and Flexer, A., 1991. Foraminiferal benthonic assemblages as indicators of pollution (an example of north- western shelf of the Black Sea). Third Annual Symp. on the Mediterranean Margin of Israel. Haifa-Israel, 5pp.

\section{Figure captions}

Figure 1. Study area and sampling location

Figure 2. Concentration of total hydrocarbons and Barium in the sediment, in function of distance from the oil cutting disposal sites.

Figure 3. A. Density and composition of the living foraminiferal faunas (> $150 \mu \mathrm{m}$ fraction observed in the first $3 \mathrm{~cm}$ of the sediment) standardized for $10 \mathrm{~cm}^{3}$ sediment volume. B. Density and composition of the living foraminiferal faunas $(63-150 \mu \mathrm{m}$ fraction observed in the first $2 \mathrm{~cm}$ of the sediment) standardized for $10 \mathrm{~cm}^{3}$ sediment volume.

Figure 4. Vertical distribution of living benthic foraminifera (> $150 \mu \mathrm{m}$ and 63-150 $\mu \mathrm{m}$ fractions) standardized for $10 \mathrm{~cm}^{3}$ sediment volume. Stations that are not represented contain less than 30 individuals per $10 \mathrm{~cm}^{3}$ sediment volume.

Figure 5. A. Total density of dead fauna (> $150 \mu \mathrm{m}$ fraction observed in the 2-3 $\mathrm{cm}$ level) standardized for $10 \mathrm{~cm}^{3}$ sediment volume. B. Percentages of Uvigerina peregrina. C. Percentages of less frequent species in the dead faunas.

Figure 6. Overview map, indicating the succession of faunal zones with decreasing environmental impact at increasing distance from the drill cutting disposal sites.

Figure 7. Cumulative percentages of all taxa indicative of natural and/or anthropogenic eutrophication and ecosystem stress, in function of distance to the drill cutting disposal sites.

\section{Plate captions:}

Plate 1. Taxa of the $>150 \mu \mathrm{m}$ fraction: 1 Uvigerina peregrina; 2. Trifarina bradyi; 3. Textularia sagittula; 4. Amphicoryna scalaris; 5. Bulimina marginata; 6. Bulimina aculeata; 7. Bulimina costata; 8. Eggerella sp.1; 9. Nonion scaphum; 10. Cancris auriculus.

Plate 2, taxa of the 63-150 $\mu \mathrm{m}$ fraction: 11. Bolivina striatula; 12. Bolivina seminuda; 13. Bolivina spathulata; 14. Casidulinoides bradyi; 15. Cassidulina carinata; 16. Trifarina pauperata; 17. Hanzawaia boueana; 18. Gyroidina sp.1; 19. Nonionella turgida.

\section{Table captions:}

Table 1: Geographical position of the sampling stations, and concentrations of total hydrocarbons and Barium in the sediment.

Table 2: Water contents, percentage of organic matter and concentrations of nutrients in the sediment of the 9 sample stations.

Table 3: Results of the leaching tests on sediments containing oily cuttings, and of a Microtox test (test of toxicity on marine bacteria). "I max" is the maximum inhibition of bacterial activity in the presence of the maximum concentration in the test tube (leachate diluted at 50\%). Minimal threshold of inhibition: 20\% (after Dalmazzone et al., 2004).

Table 4: Results of aerobic biodegradation after 90 days exposure, expressed in percentage of degraded hydrocarbons. Minimum $(*)$ and maximum $\left({ }^{* *}\right)$ values take into account the extraction efficiency from the abiotic sample (after Dalmazzone et al., 2004).

Table 5: A. Total numbers of living benthic foraminifera (> $150 \mu \mathrm{m}$ fraction, not standardized for sediment volume) found in all sampled sediment intervals. B. Same data, standardized for $10 \mathrm{~cm}^{3}$ sediment volume. 
Table 6: A. Total numbers of living benthic foraminifera (63-150 $\mu \mathrm{m}$ fraction, not standardized for sediment volume) found in all sampled sediment intervals. B. Same data, standardized for $10 \mathrm{~cm}^{3}$ sediment volume.

Table 7: A. Total amounts of dead/subfossil foraminifera in level D $(2-3 \mathrm{~cm})$, and the PB-ratio (with $\mathrm{PB}=\mathrm{P} /(\mathrm{P}+\mathrm{B}))$, expressed as the percentage of planktonic foraminifera within the total foraminiferal assemblage. B. Same data, standardized for $10 \mathrm{~cm}^{3}$ sediment volume.

\section{Appendix captions (for electronic publication only)}

\section{Appendix 1: Taxonomic notes.}

Appendix 2: Census data for the living fauna in the $>150 \mu \mathrm{m}$ fraction.

Appendix 3: Composition and percentages of the total living fauna ( $>150 \mu \mathrm{m}$ fraction) for the first 3 $\mathrm{cm}$ of the sediment (total sediment volume $=37.7 \mathrm{~cm}^{3}$ ).

Appendix 4: Census data for the living fauna in the 63 - $150 \mu \mathrm{m}$ fraction.

Appendix 5: Composition and percentages of the living fauna (63 - $150 \mu \mathrm{m}$ fraction) for the first $2 \mathrm{~cm}$ of the sediment (total volume $=25.2 \mathrm{~cm}^{3}$ )

Appendix 6: Census data and percentages of the dead/subfossil fauna determined in level D $(2-3 \mathrm{~cm}$ depth; total sediment volume $=12.6 \mathrm{~cm}^{3}$. 
Figure 1

$11^{\circ} 33^{\prime} 25 \quad 11^{\circ} 33^{\prime} 50 \quad 11^{\circ} 33^{\prime} 75 \quad 11^{\circ} 34^{\prime} 00 \quad 1 I^{\circ} 34^{\prime} 25 \quad L^{\mathrm{u}} 34^{\circ} 50 \quad I^{\circ} 34^{\prime} 75$

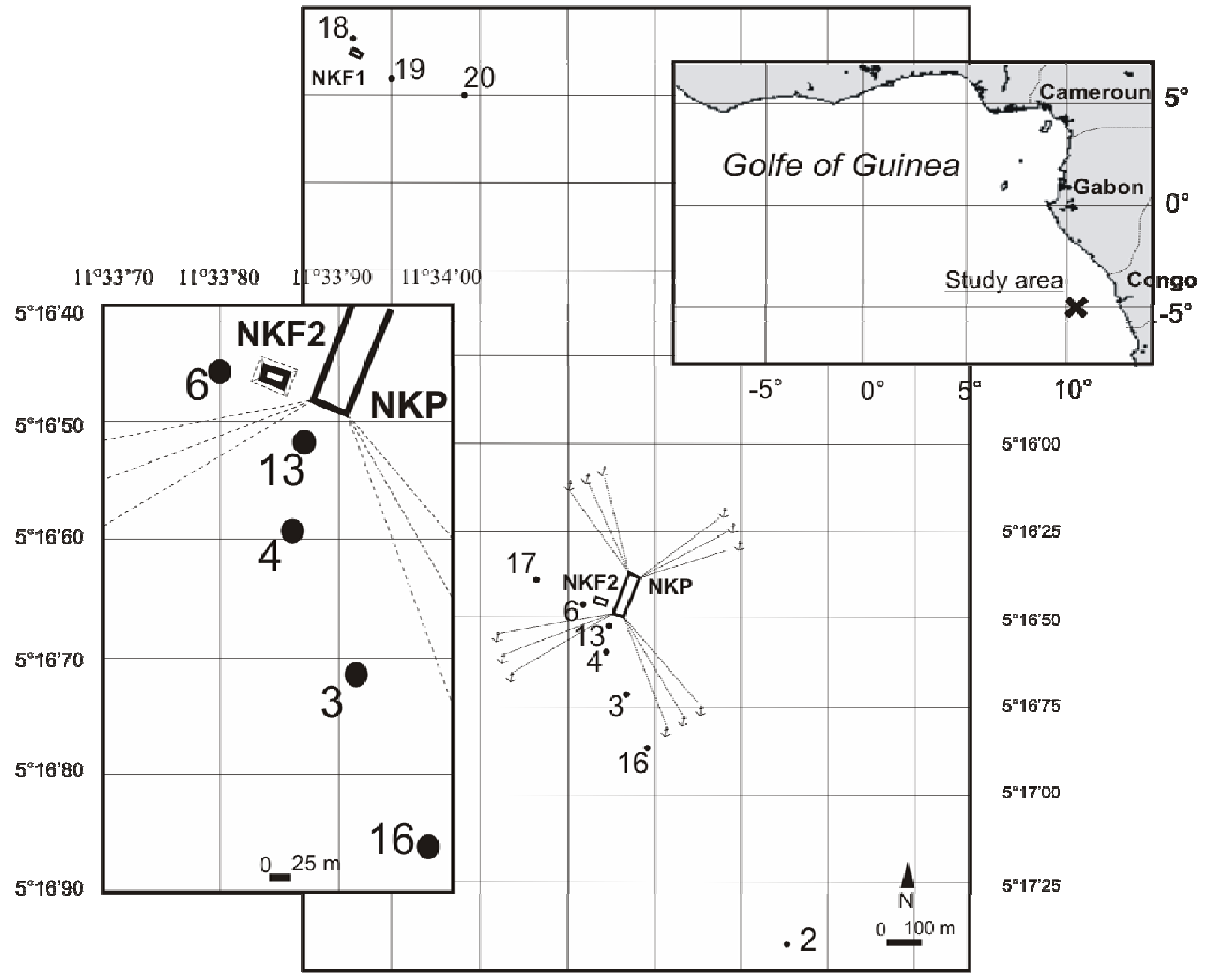


Figure 2
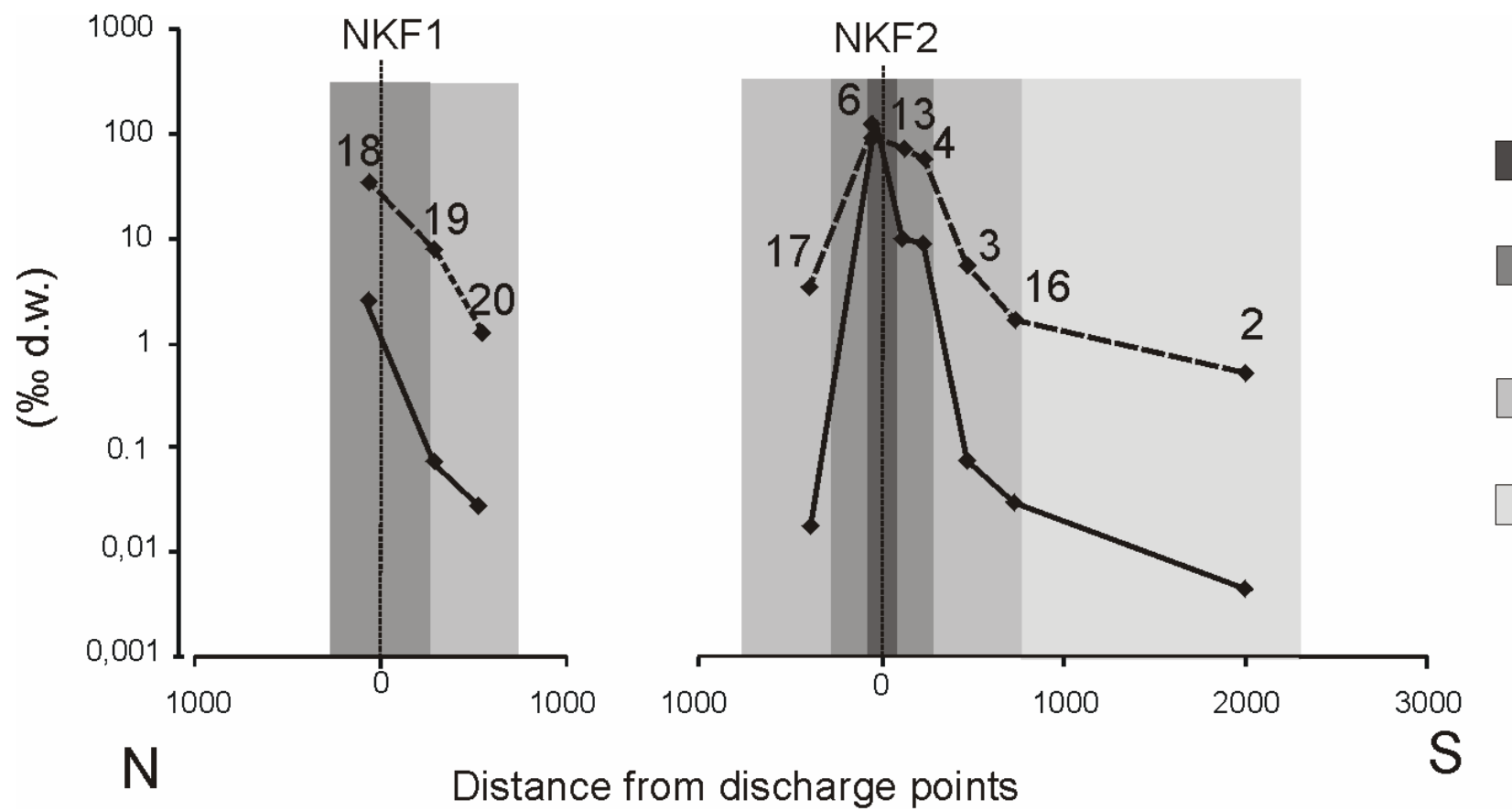

Zone 1: Highly affected zone

Zone 2: Little affected zone by Hydrocarbons Higly afected zone by Barium

Zone 3 : Transition zone

Zone 4 : Non-impacted zone

---- Barium

Hydrocarbons

N Distance from discharge points

$\mathrm{S}$ 
Figure 3
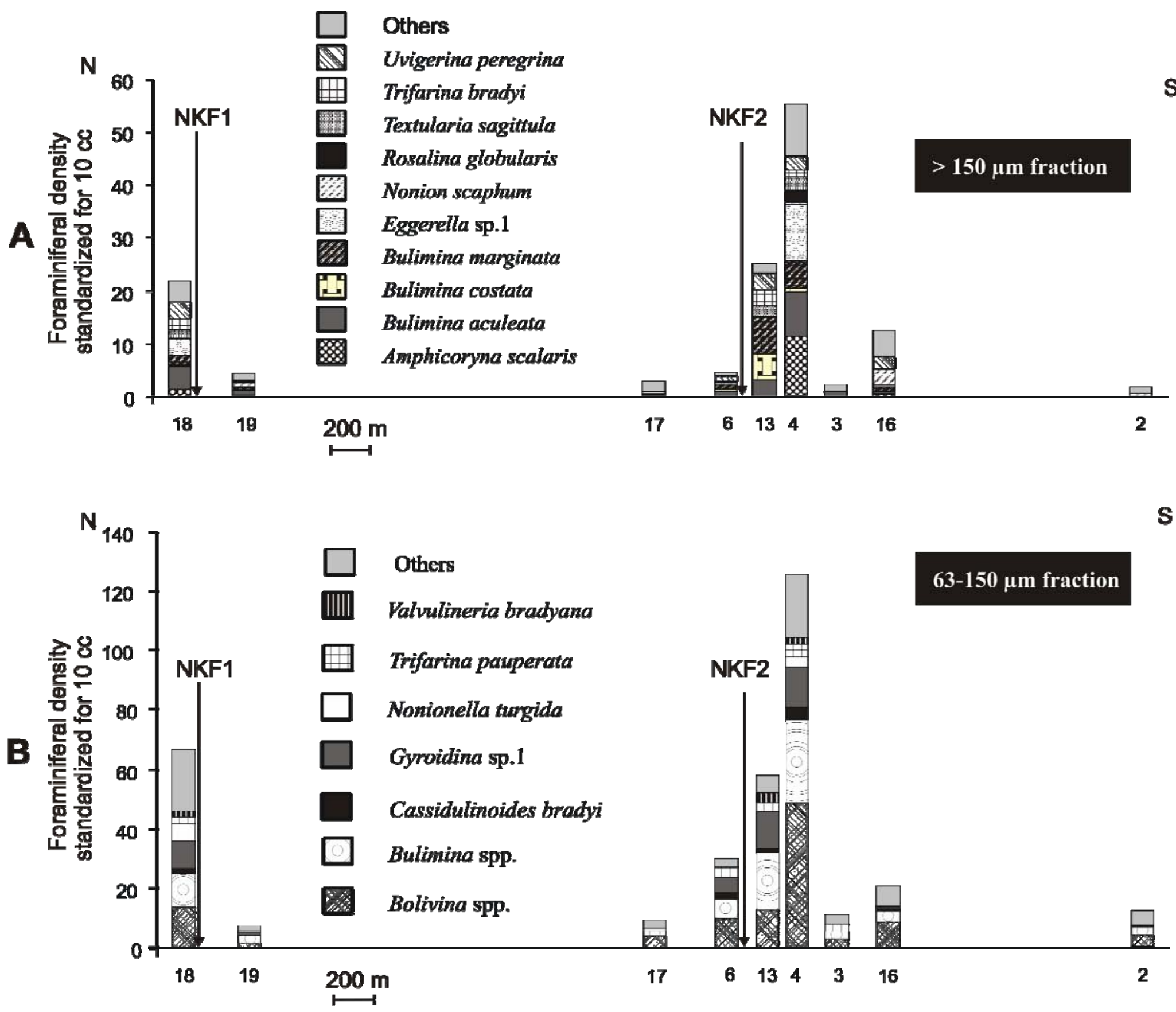
Figure 4

$>150 \mu \mathrm{m}$ fraction

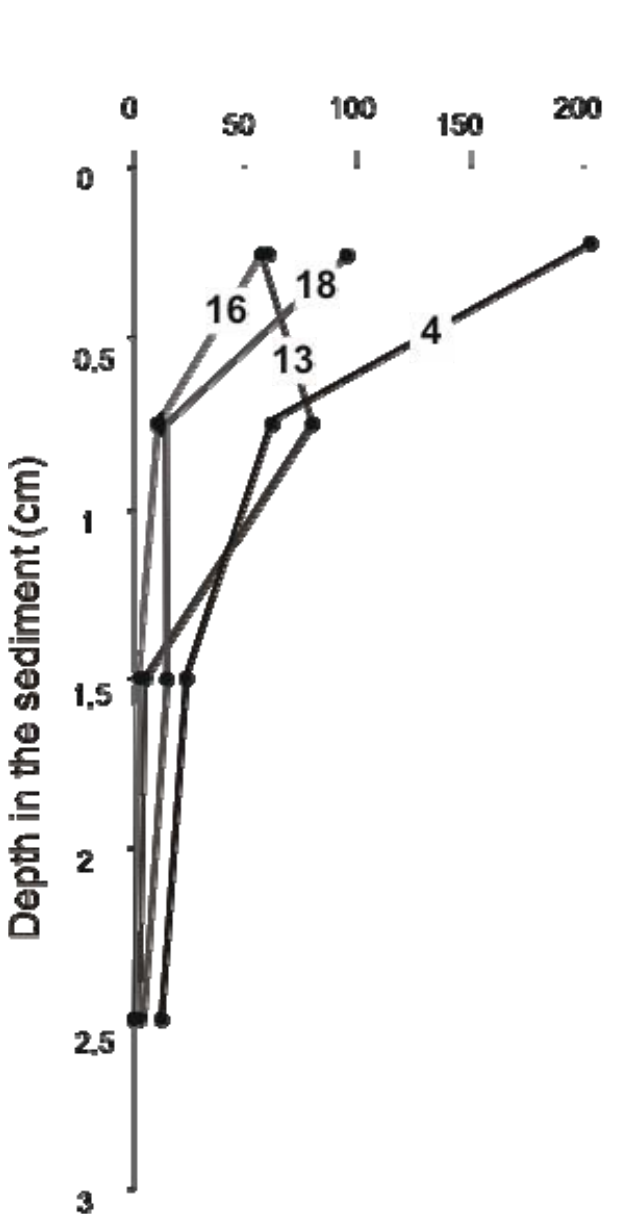

\section{$63-150 \mu \mathrm{m}$ fraction}

Number of individuals per $10 \mathrm{~cm}^{3}$

$\begin{array}{cccccccccc}250 & 0 & 50 & 100 & 150 & 200 & 250 & 300 & 350 & 400 \\ 1 & 0 & 1 & 1 & - & 1 & 1 & 1 & 1 & 1\end{array}$

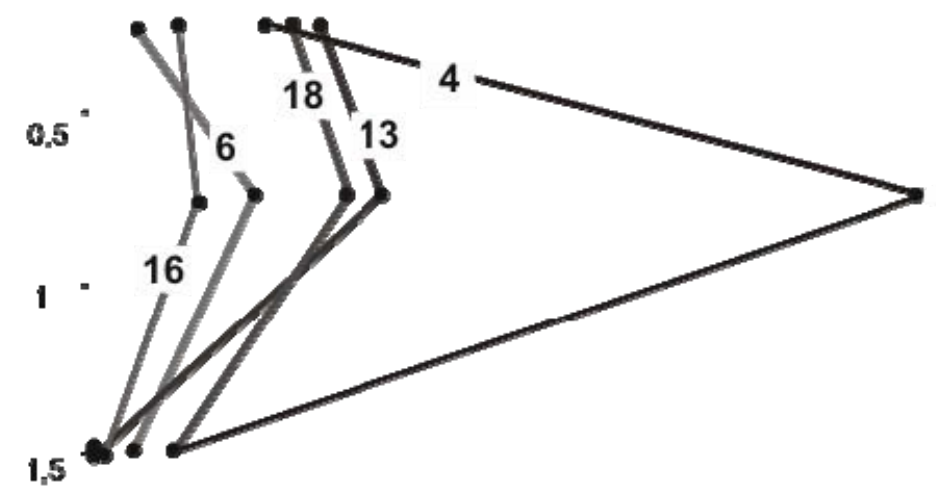

$2^{\circ}$

$2,5^{\circ}$

3 
Figure 5

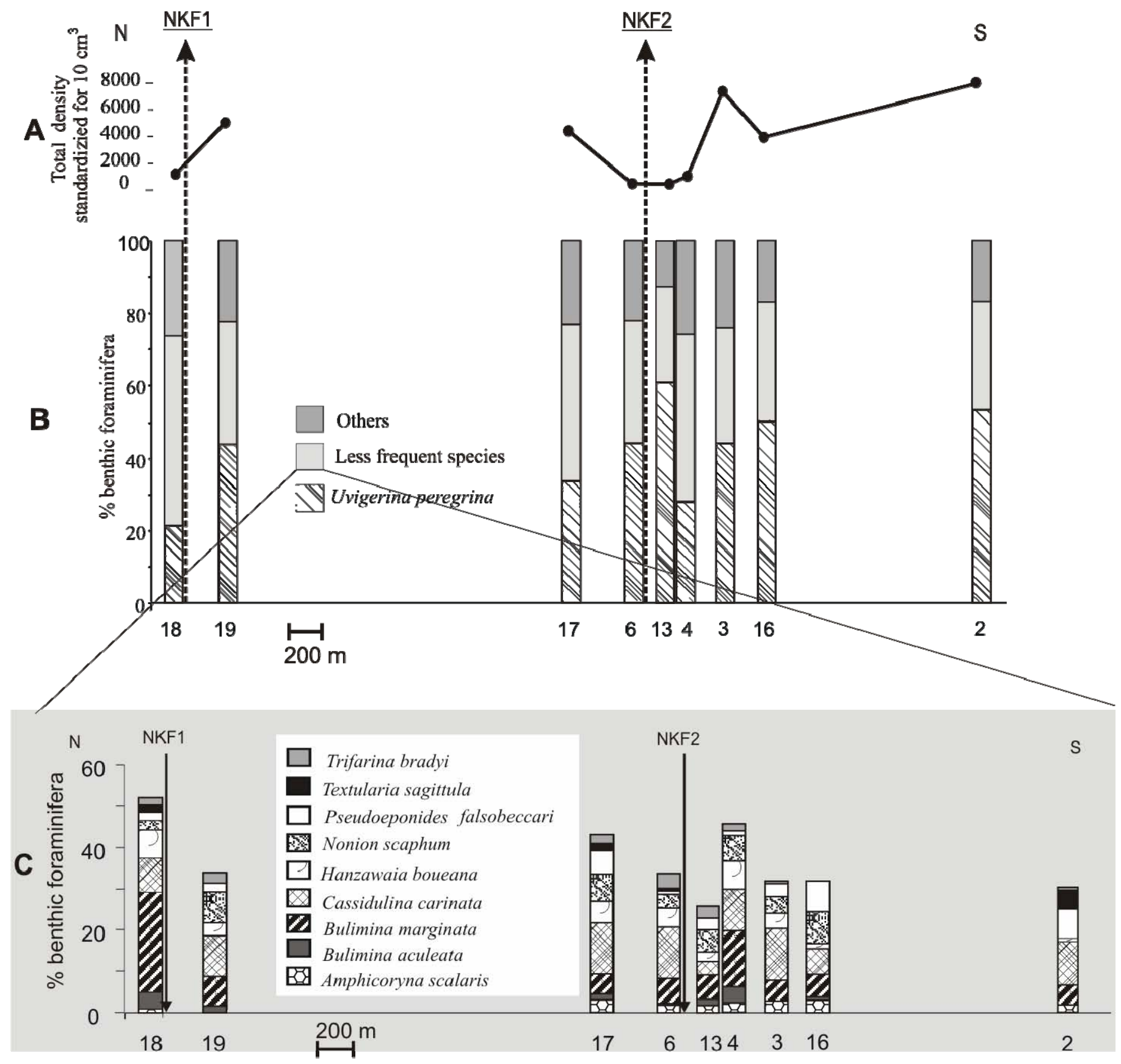


Figure 6

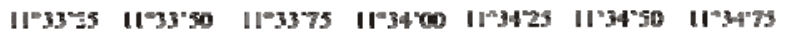

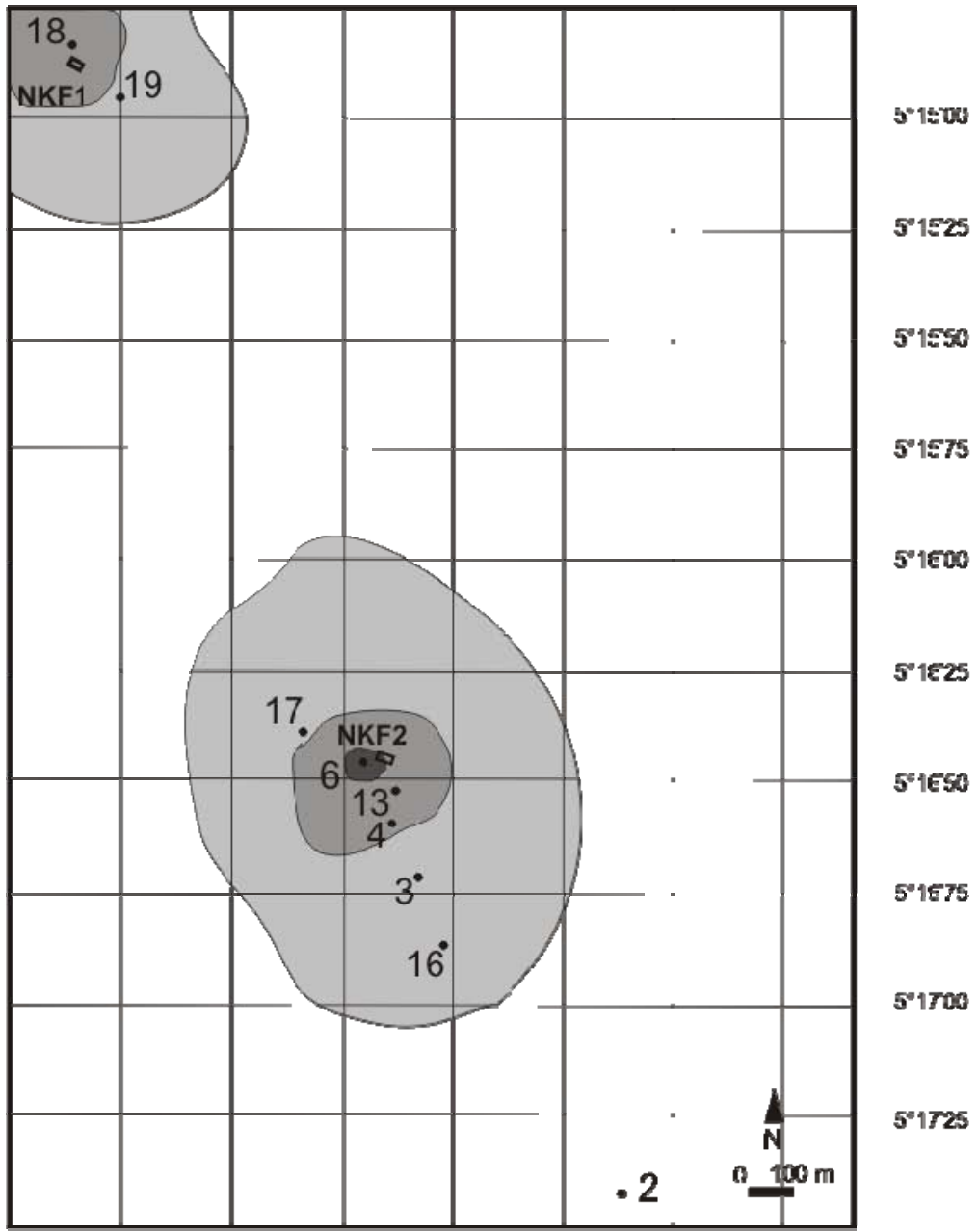


Figure 7

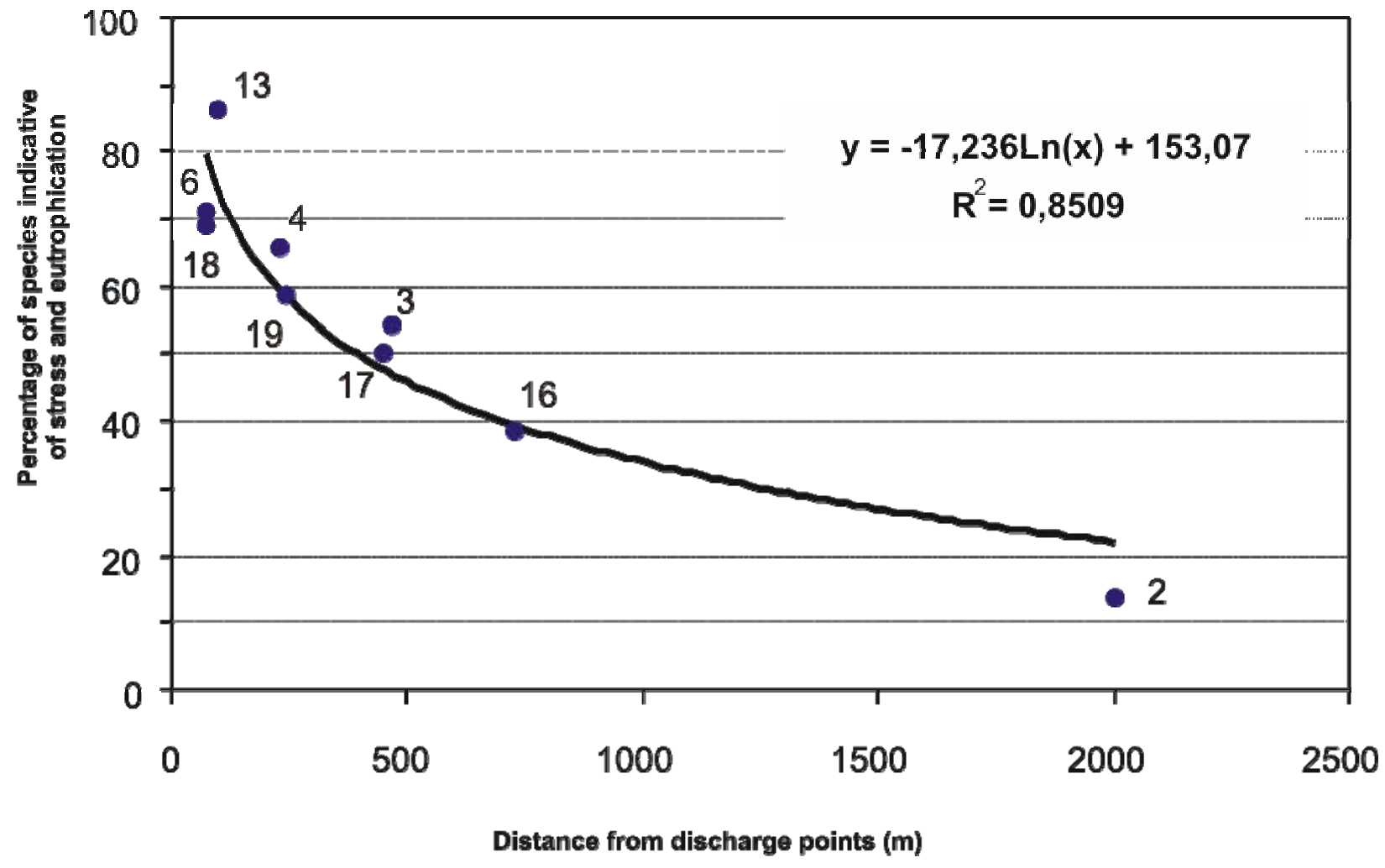


Plate 1
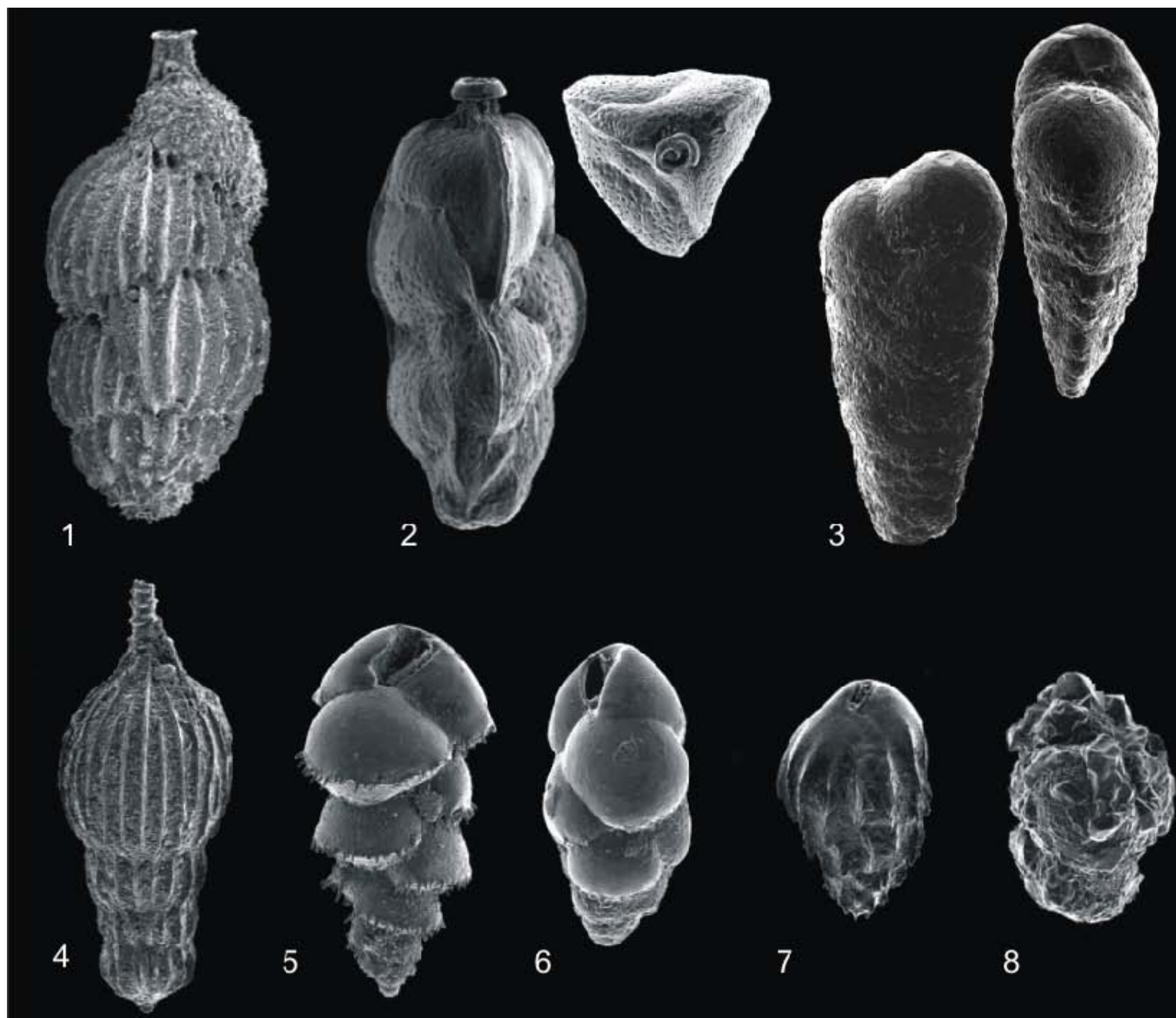

8

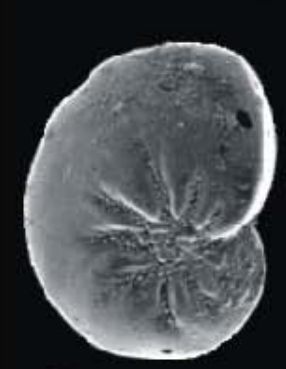

9
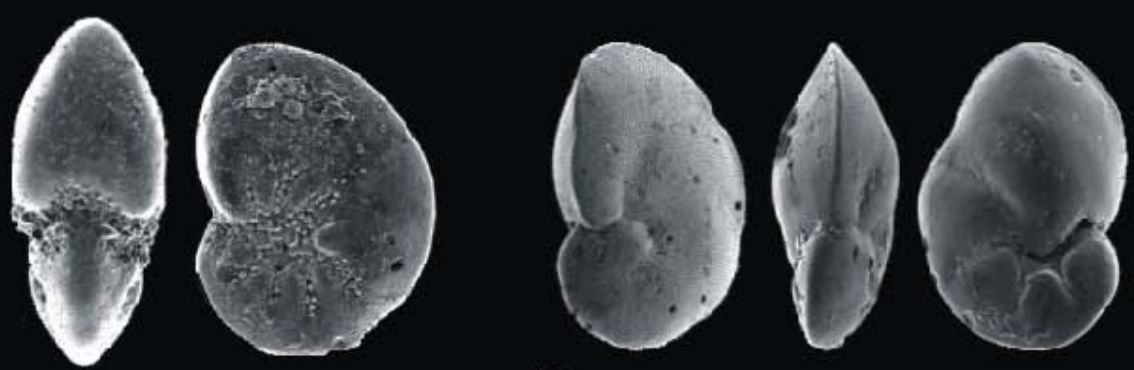

10

$100 \mu \mathrm{m}$ 
Plate 2

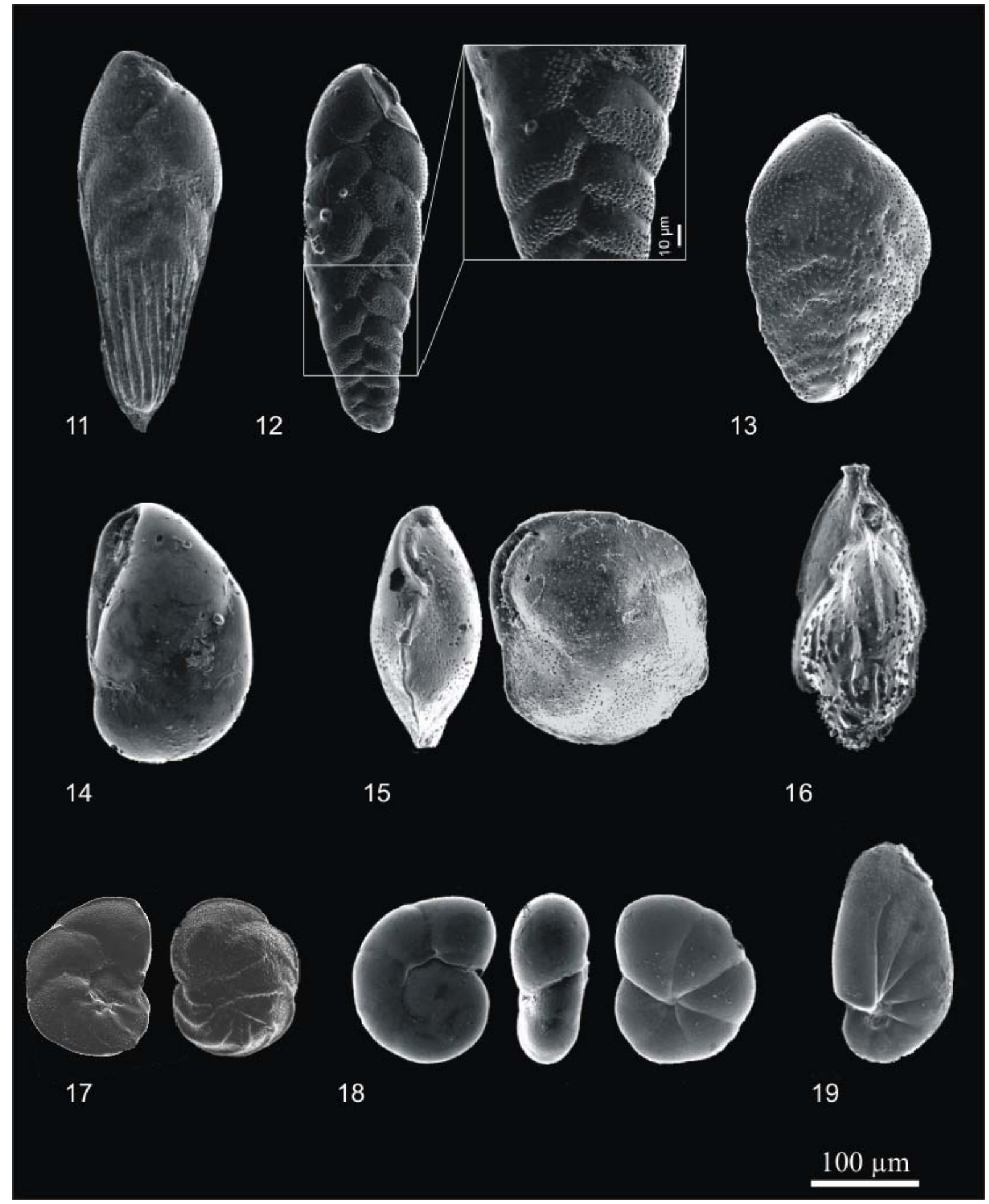




\section{Table 1}

\begin{tabular}{|c|c|c|c|c|c|}
\hline Station & Localisation & Latitude & Longitude & $\begin{array}{c}\text { Total } \\
\text { haydrocarbons } \\
\text { (\%o d.w.) }\end{array}$ & $\begin{array}{c}\text { Barium } \\
\text { (\%o d.w.) }\end{array}$ \\
\hline 2 & $\begin{array}{l}\text { 2000m from } \\
\text { NKF2 (Sud) }\end{array}$ & $05^{\circ} 17.419 \mathrm{~S}$ & $11^{\circ} 34.379 \mathrm{E}$ & $<0.010$ & 0.482 \\
\hline 3 & $\begin{array}{l}\text { 470m from } \\
\text { NKF2 (Sud) }\end{array}$ & $05^{\circ} 16.711 \mathrm{~S}$ & $11^{\circ} 33.916 \mathrm{E}$ & 0.076 & 5.340 \\
\hline 4 & $\begin{array}{l}\text { 230m from } \\
\text { NKF2 (Sud) }\end{array}$ & $05^{\circ} 16.588 \mathrm{~S}$ & $11^{\circ} 33.861 \mathrm{E}$ & 8.815 & 56.300 \\
\hline 6 & $\begin{array}{c}\text { 70m from } \\
\text { NKF2 (Ouest) }\end{array}$ & $05^{\circ} 16.453 \mathrm{~S}$ & $11^{\circ} 33.802 \mathrm{E}$ & 109.000 & 94.600 \\
\hline 13 & $\begin{array}{l}\text { 100m from } \\
\text { NKF2 (Sud) }\end{array}$ & $05^{\circ} 16.519 \mathrm{~S}$ & $11^{\circ} 33.874 \mathrm{E}$ & 9.970 & 77.600 \\
\hline 16 & $\begin{array}{l}\text { 730m from } \\
\text { NKF2 (Sud) }\end{array}$ & $05^{\circ} 16.839 \mathrm{~S}$ & $11^{\circ} 33.966 \mathrm{E}$ & 0.029 & 1.530 \\
\hline 17 & $\begin{array}{c}450 \mathrm{~m} \text { from } \\
\text { NKF2 (Ouest) }\end{array}$ & $05^{\circ} 16.365 \mathrm{~S}$ & $11^{\circ} 33.654 \mathrm{E}$ & 0.018 & 3.480 \\
\hline 18 & $\begin{array}{l}\text { 70m from } \\
\text { NKF1 (Nord) }\end{array}$ & $05^{\circ} 14.996 \mathrm{~S}$ & $11^{\circ} 33.131 \mathrm{E}$ & 2.667 & 36.000 \\
\hline 19 & $\begin{array}{l}\text { 250m from } \\
\text { NKF1 (Sud) }\end{array}$ & $05^{\circ} 14.901 \mathrm{~S}$ & $11^{\circ} 33.251 \mathrm{E}$ & 0.084 & 9.760 \\
\hline 20 & $\begin{array}{c}500 \text { m from } \\
\text { NKF1 (sud-est) }\end{array}$ & $05^{\circ} 15.001 \mathrm{~S}$ & $11^{\circ} 33.441 \mathrm{E}$ & 0.040 & 1.270 \\
\hline
\end{tabular}


Table 2

\begin{tabular}{|c|c|c|c|c|c|c|}
\hline Platforms & Station & $\begin{array}{l}\text { Distance from the discharge } \\
\text { points } \\
(\mathrm{m})\end{array}$ & $\begin{array}{l}\text { Water } \\
\text { content } \\
(\%)\end{array}$ & $\begin{array}{c}\text { Organic } \\
\text { matter } \\
\text { (\% d.w.) }\end{array}$ & $\begin{array}{c}\text { Total } \\
\text { nitrogen } \\
\text { (\% d.w.) }\end{array}$ & $\begin{array}{c}\text { total } \\
\text { phosphorous } \\
\text { (ppm d.w.) }\end{array}$ \\
\hline \multirow{7}{*}{ NKF2 } & 6 & 70 & 35.3 & 18.4 & 0.14 & 778 \\
\hline & 13 & 100 & 42.5 & 11.3 & 0.19 & 522 \\
\hline & 4 & 230 & 45.8 & 11.3 & 0.19 & 1020 \\
\hline & 17 & 380 & 44.8 & 12.8 & 0.16 & 770 \\
\hline & 3 & 470 & 49.8 & 12.5 & 0.16 & 863 \\
\hline & 16 & 730 & 47.9 & 11.3 & 0.18 & 810 \\
\hline & 2 & 2000 & 48.6 & 12.9 & 0.19 & 1023 \\
\hline \multirow{2}{*}{ NKF1 } & 18 & 70 & 48.5 & 12.0 & 0.25 & 824 \\
\hline & 19 & 250 & 48.4 & 11.0 & 0.19 & 1461 \\
\hline
\end{tabular}


Table 3

\begin{tabular}{cccc}
\hline Stations & TOC (mg/l) & $\begin{array}{c}\text { Total hydrocarbons } \\
(\mathbf{\mu g} / \mathbf{l})\end{array}$ & $\begin{array}{c}\text { Microtox } \\
\text { I max }\end{array}$ \\
\hline $\mathbf{2}(\mathbf{2 0 0 0} \mathbf{~ m ~ S )}$ & 73 & 16 & $<$ threshold \\
$\mathbf{4}(\mathbf{2 3 0} \mathbf{~ \mathbf { S } )}$ & 72 & 90 & 50 \\
$\mathbf{1 3}(\mathbf{1 0 0} \mathbf{~ m ~ S})$ & 90 & 111 & $<$ threshold \\
$\mathbf{6 ( 7 0} \mathbf{~ m ~ W )}$ & 137 & 107 & <threshold \\
\hline
\end{tabular}


Table 4

\begin{tabular}{ccc}
\hline Stations & Sediment (g) & $\begin{array}{c}\text { Degraded } \\
\text { hydrocarbons (\%) }\end{array}$ \\
\hline & 7.6 & $86^{*}-88^{* *}$ \\
$\mathbf{6}$ & 6.8 & $65-71$ \\
$\mathbf{( 7 0} \mathbf{~ m )}$ & 6.5 & $79-82$ \\
& 6.1 & $84-87$ \\
\hline & 5.8 & $48-56$ \\
$\mathbf{1 3}$ & 7.4 & $42-51$ \\
$\mathbf{( 1 0 0} \mathbf{~})$ & 7.3 & $38-48$ \\
\hline & 5.7 & $79-83$ \\
$\mathbf{4}$ & 5.8 & $73-79$ \\
$\mathbf{( 2 3 0} \mathbf{~ m})$ & 5.5 & $79-83$ \\
& 5.2 & $73-79$ \\
\hline
\end{tabular}


Table 5

\begin{tabular}{cccccccccc}
\hline Station & $\mathbf{2}$ & $\mathbf{3}$ & $\mathbf{4}$ & $\mathbf{6}$ & $\mathbf{1 3}$ & $\mathbf{1 6}$ & $\mathbf{1 7}$ & $\mathbf{1 8}$ & $\mathbf{1 9}$ \\
\hline $0-0,5 \mathrm{~cm}$ & 2 & 1 & 129 & 11 & 36 & 38 & 7 & 60 & 4 \\
$0,5-1 \mathrm{~cm}$ & 2 & 0 & 40 & 2 & 50 & 8 & 3 & 7 & 4 \\
$1-2 \mathrm{~cm}$ & 3 & 6 & 30 & 5 & 7 & 3 & 1 & 18 & 1 \\
$2-3 \mathrm{~cm}$ & 0 & 1 & 16 & 0 & 4 & 0 & 0 & 0 & 8 \\
\hline Total & $\mathbf{7}$ & $\mathbf{8}$ & $\mathbf{2 1 5}$ & $\mathbf{1 8}$ & $\mathbf{9 7}$ & $\mathbf{4 9}$ & $\mathbf{1 1}$ & $\mathbf{8 5}$ & $\mathbf{1 7}$ \\
\hline
\end{tabular}

\begin{tabular}{cccccccccc}
\hline Station & $\mathbf{2}$ & $\mathbf{3}$ & $\mathbf{4}$ & $\mathbf{6}$ & $\mathbf{1 3}$ & $\mathbf{1 6}$ & $\mathbf{1 7}$ & $\mathbf{1 8}$ & $\mathbf{1 9}$ \\
\hline $0-0,5 \mathrm{~cm}$ & 3 & 2 & 205 & 17 & 57 & 60 & 11 & 95 & 6 \\
$0,5-1 \mathrm{~cm}$ & 3 & 0 & 63 & 3 & 79 & 13 & 5 & 11 & 6 \\
$1-2 \mathrm{~cm}$ & 2 & 5 & 24 & 4 & 6 & 2 & 1 & 14 & 1 \\
$2-3 \mathrm{~cm}$ & 0 & 1 & 13 & 0 & 3 & 0 & 0 & 0 & 6 \\
\hline
\end{tabular}


Table 6

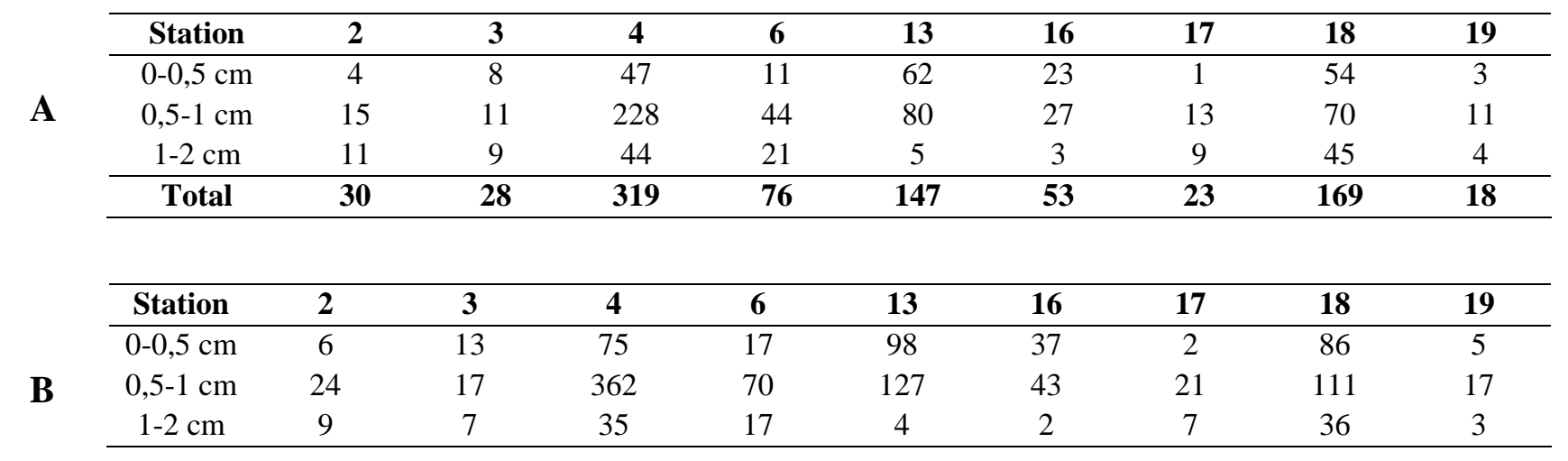


Table 7

\begin{tabular}{llccccccccc}
\cline { 2 - 9 } A & Station & 2D & 3D & 4D & 6D & 13D & 16D & 17D & 18D & 19D \\
\cline { 2 - 9 } & Total benthic foraminifera & 9728 & 9301 & 1328 & 542 & 555 & 5077 & 6176 & 1543 & 6336 \\
& Total planktonic foraminifera & 17250 & 12843 & 1195 & 450 & 677 & 7573 & 7968 & 903 & 7232 \\
& PB - ratio (\% planktonic) & 63.9 & 58.0 & 47.4 & 45.4 & 55.0 & 59.9 & 56.3 & 36.9 & 53.3 \\
\cline { 2 - 10 } & & & & & & & & & & \\
\cline { 2 - 9 } & Station & 2D & 3D & 4D & 6D & 13D & 16D & 17D & 18D & 19D \\
\cline { 2 - 9 } & Total benthic foraminifera & 7321 & 7382 & 1054 & 430 & 440 & 4029 & 4902 & 1225 & 5029 \\
& Total planktonic foraminifera & 13690 & 10193 & 948 & 357 & 537 & 6010 & 6324 & 717 & 5740 \\
& PB - ratio (\% planktonic) & 63.9 & 58.0 & 47.4 & 45.4 & 55.0 & 59.9 & 56.3 & 36.9 & 53.3 \\
\hline
\end{tabular}

